University for Business and Technology in Kosovo

UBT Knowledge Center

Oct 27th, 9:00 AM - 10:30 AM

\title{
Creating and Curating New Knowledge: A North American University Case Study
}

\author{
Niraj Chaudhary \\ University of the Pacific, nchaudhary@pacific.edu \\ Michele Gibney \\ University of the Pacific, mgibney@pacific.edu
}

Follow this and additional works at: https://knowledgecenter.ubt-uni.net/conference

Part of the Education Commons

\section{Recommended Citation}

Chaudhary, Niraj and Gibney, Michele, "Creating and Curating New Knowledge: A North American University Case Study" (2018). UBT International Conference. 122.

https://knowledgecenter.ubt-uni.net/conference/2018/all-events/122

This Event is brought to you for free and open access by the Publication and Journals at UBT Knowledge Center. It has been accepted for inclusion in UBT International Conference by an authorized administrator of UBT Knowledge Center. For more information, please contact knowledge.center@ubt-uni.net. 


\title{
Creating and Curating New Knowledge: A North American University Case Study
}

\author{
Niraj Chaudhary ${ }^{1}$ and Michele Gibney ${ }^{2}$ \\ ${ }^{1}$ University of the Pacific, 3601 Pacific Ave., Stockton, CA 95211, USA, \\ nchaudhary@pacific.edu \\ ${ }^{2}$ University of the Pacific, 3601 Pacific Ave., Stockton, CA 95211, USA, \\ mgibney@pacific.edu
}

\begin{abstract}
In the Fall of 2017, a cross disciplinary team at University of the Pacific in Stockton, California, USA worked together to identify ways of creating new knowledge for an undergraduate engineering course titled Building Information Modeling. The team included faculty from the School of Engineering and Computer Science and technical staff from the Cube, a digital makerspace in the library. Students were tasked to design and model a onestory building to house the University of the Pacific Garden Program on campus. The cross-disciplinary team had the students explore an immersive way of seeing the building model by using a Virtual Reality (VR) system. As the University for Business and Technology Knowledge Center concept acknowledges, it is important to curate local knowledge so that future generations can build upon it. At Pacific, the cross disciplinary team was not content with merely producing exemplary student work; they opted to involve the Digital Repository Coordinator in the project and she uploaded all student projects to the University's digital repository, where they will now serve as proof of concept for students in 2018 to build upon in their own course work.
\end{abstract}

Keywords: Virtual Reality, Teaching, Learning, Higher Education, Institutional Repository

\section{Introduction}

Implementing technology like VR in the classroom can lead to new ways of thinking and doing for students, including obtainment of new skills which can serve them in future classes as well as beyond their academic studies. Disseminating newly created knowledge through an online repository of University scholarship leads to increased visibility of work produced on campus, which contributes to the general knowledge base for successive semesters of students at Pacific. However, as the works are also freely available to anyone online, through, for example, Creative Commons licensure, students are also contributing to new knowledge in teaching, learning and research at other institutions. This paper will explore both the technical elements of utilizing VR 
technology in the classroom along with the benefits of making University produced knowledge freely and globally available online.

\subsection{The Cube}

Aspiring to be the intellectual hub of the campus, in the summer of 2017, University of the Pacific library launched a makerspace, The Cube. A makerspace provides opportunities to engage learners through experiential learning and are "defined not by specific equipment but by a guiding purpose to provide people with a place to experiment, create, and learn" [1].

The purpose of The CUBE is to provide collaborative learning opportunities that engage students to create new forms of knowledge. The Cube promotes experimentation with curriculum design and the scholarship of teaching and learning in a flexible, collaborative, and technology-rich environment. The Cube provides access to an array of 3D technologies, including Virtual Reality head-mounted displays (HMDs), Virtual Reality capable computers and 3D modeling software, $360^{\circ}$ cameras, and 3D printers.

\subsection{Scholarly Commons}

In 2016, the University of the Pacific Libraries purchased the Digital Commons institutional repository software created by bepress. They also hired a Digital Repository Coordinator who helped to implement the nascent, Pacific-branded repository, named Scholarly Commons (SC).

SC highlights the intellectual and creative output of University of the Pacific faculty, students, alumni and staff, ensuring long-term preservation and worldwide electronic accessibility. Included in SC are: journal articles, conference papers, theses and dissertations, Pacific historical publications (newsletters, commencement programs, etc.), digital items from the Holt-Atherton Special Collections, and other materials, including records created in The Cube.

\section{Virtual Reality in American Higher Education}

In American Universities, Virtual Reality technologies are enabling new approaches to teaching, learning and research. Historical reconstructions, simulation training, immersive storytelling, collaboration, and architecture renderings are just some of the areas universities look to integrate Virtual Reality in order to enhance learning experiences and outcomes [2].

For example, at University of the Pacific, students from cross-disciplines created a Virtual Reality museum exhibit using historical research and interviews, which allowed you to virtually walk the streets of Stockton's once-vibrant Filipino neighborhood, and learn the history of a place that was once home to the largest population of Filipinos in the United States. 


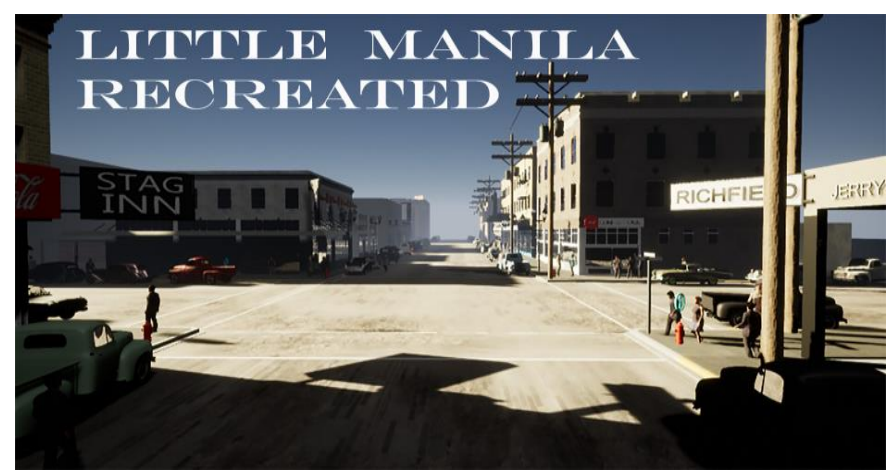

Fig. 1. Example of historical reconstruction. A screenshot of Virtual Reality museum developed by University of the Pacific. Source - http://www.digitaldeltas.org/

At Harvard University, using Virtual Reality, students in French language and culture classes were able to meet native speakers at parties in their homes and hear conversations in cafes in France, all without leaving their classroom in United States.

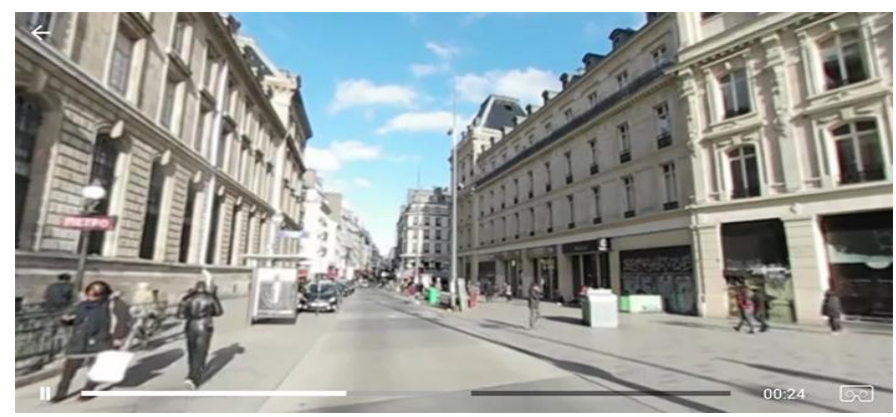

Fig. 2. Example of immersive storytelling. A screenshot from the VR narrative of the La République neighborhood in Paris. Source - https://er.educause.edu/blogs/2018/8/threeexamples-from-the-field-ar-and-vr-in-teaching-and-research

At Yale University, the Immersive Tools for Learning Basic Anatomy project enables students to further their understanding of anatomical systems and medical procedures. Outputs of medical imaging devices such as CT scans are converted into 3D models, which then are brought into Virtual Reality to simulate human anatomy, allowing students an inside view of specific bodies [3]. Massachusetts Institute of Technology is developing a Virtual Reality walkthrough inside a cell in which objects within the cell are appropriately scaled. Inside the virtual cell, if something needs repair, a cross-disciplinary team of VR developers and subject matter experts must communicate continually and effectively in order to repair the cell [4].

VR is being used as a media tool for journalism students at the University of Oklahoma [5]; as virtual crime scenes for study by criminal justice students at George Washington University [6]; and at Drexel University, they have partnered with 3 Dream, a technology company that works on $3 \mathrm{D}$ animation, to create a database of 
over 250,000 "artifacts" - VR and AR images, 3D objects, and 360 degree panoramas - for use in the classroom,[7].

As can be seen by this wealth of examples, VR technology has a myriad number of uses in the higher educational environment and is just beginning to gain popularity and momentum in that sphere. A recent Gartner study estimates $60 \%$ of US based higher education institutions will be using VR to create an enhanced simulation and learning environments by 2021. [8]

\section{Creating With The Cube}

In the fall of 2017, a cross disciplinary team at University of the Pacific worked together to identify ways of creating new knowledge for an undergraduate engineering course titled Building Information Modeling. The team included faculty from the School of Engineering and Computer Science (SOECS) and technical staff from The Cube. Students were tasked to design and model a one-story building to house the University of the Pacific Garden Program on campus. Project description and guidelines were shared with The Cube staff.

The cross disciplinary team had the students explore an immersive way of seeing the building model by using a Virtual Reality system. For 3D modeling, students selected Revit software to design their one-story building. The Cube provided the hardware, Oculus Rift Virtual Reality system. Along with students from the class, the Cube staff did a comprehensive review of available software and plugins that converted the 3D models into a Virtual Reality experience. A solution was identified and tested with positive results. During the final presentations, students described their project using PowerPoint slides, while the audience wore the Virtual Reality system to virtually walk through $3 \mathrm{D}$ models.

\section{Curating with Scholarly Commons}

Staff from The Cube discussed with the SOECS faculty that at the end of the course, the students' final presentation materials should be included in Pacific's institutional repository, Scholarly Commons (SC). The reasons for this were twofold.

1. Display student work to the world -- this would have benefits for the students as they could point to their work with a static URL when applying for jobs or further academic studies. There are also potential benefits in attracting new students or new faculty if prospectives see the work occurring at Pacific and want to embark on similar projects in collaboration with The Cube and SC.

2. A repository of generated knowledge from the class with unlimited storage and static URLs would have beneficial consequences when the course is taught again. Previous work would be available for the future students to reference and build upon in their own projects.

Efforts were made to secure creator permission for the work to go in SC. Copyright ownership of the work remains with the creators and SC merely serves as a hosting platform for their materials. 
From the initial course in Fall 2017, there were a total of six produced projects from student groups, which are now housed in SC at https://scholarlycommons.pacific.edu/bim_projects/

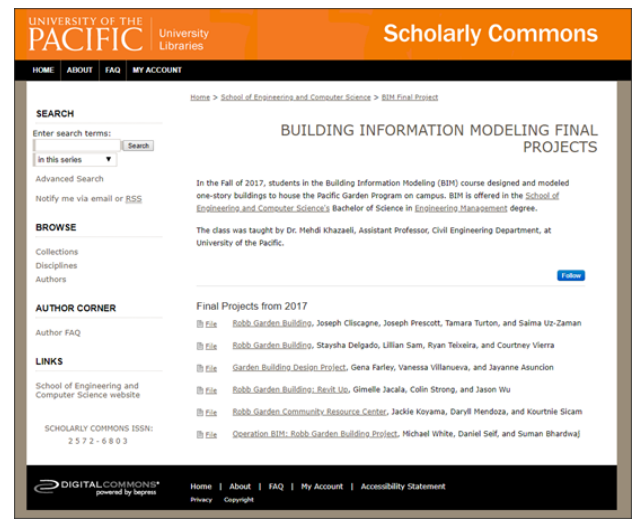

Fig. 3. Homepage for Building Information Modeling Final Projects https://scholarlycommons.pacific.edu/bim projects/ [9]

Introductory text providing context to the collection was included at the top of the main content window, the collection is nested underneath the Department (SOECS) on the repository, and a link to the SOECS website was added to the sidebar as well (see Figure 3). Each record had basic metadata added including title, creators, document type, publication date, abstract, recommended citation, and disciplinary categories (see Figure 4).

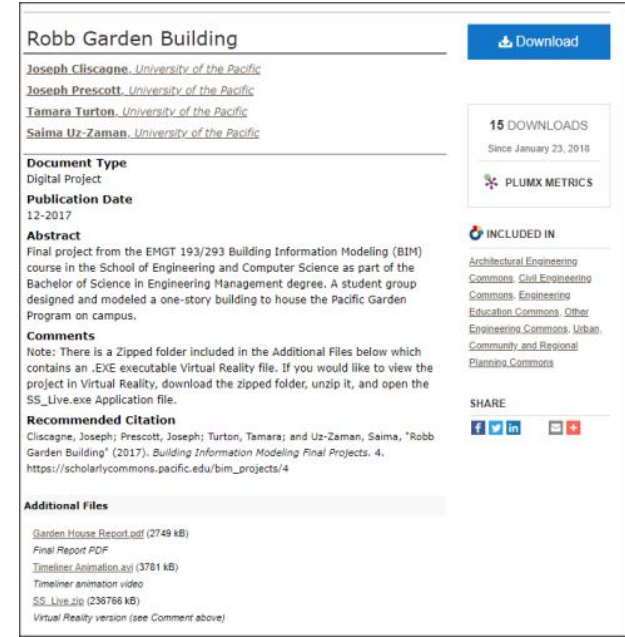

Fig. 4. Sample record page - https://scholarlycommons.pacific.edu/bim projects/4/ [10]

While the main "Download" button will access the student groups' presentation files, "Additional Files" are included at the bottom of the record page including their 
final reports, timeliner animation videos, rendering animation videos, and zipped VR .exe files.

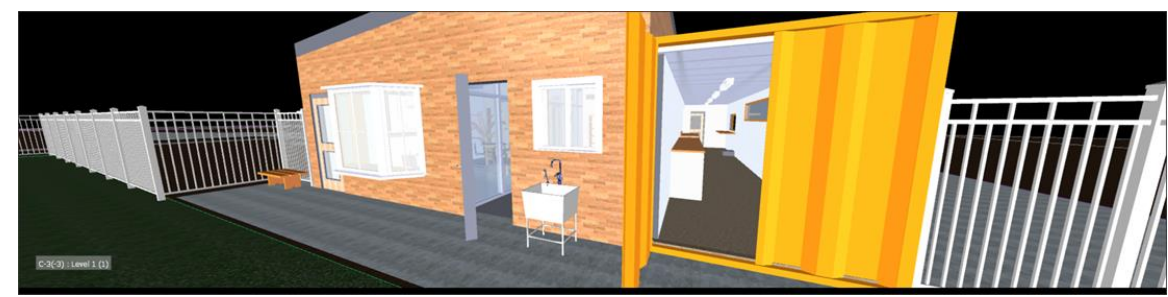

Fig. 5. Example rendering animation video -

https://scholarlycommons.pacific.edu/bim projects/1/ [11]

Since the projects were posted in January 2018, there have been 72 unique visitors to the collection. It will be interesting to see how use increases as more time passes and new projects are added to the collection. In addition, educational databases of VR projects are in their infancy and much work is still being done on consistent metadata standards across repositories. This is a field to watch carefully as collaborative research is currently being done to initiate and define standards and best practices [12].

\section{Conclusion}

We had an opportunity to forge a different path and explore something beyond traditional ways of creating new content showcasing student projects. As a proof of concept on how University Libraries services - The Cube and SC - could work in conjunction with faculty and students to create and curate technologically rich projects, the Building Information Modeling course was a complete success. SOECS faculty and students were engaged in the creation process and have been appreciative of the curation. Pacific University Libraries are now in a good position to share this initial project with the rest of campus and discuss additional collaborations within SOECS as well as with other departments as they relate to teaching and learning with VR technology. Here at Pacific, we look forward to continued exploration of advancing knowledge by integrating emerging technologies to create and curate student and faculty projects.

\section{References}

1. Fisher, E.: Makerspaces Move into Academic Libraries. ACRL TechConnect. (2012, November 28). Retrieved from: https://acrl.ala.org/techconnect/post/makerspaces-moveinto-academic-libraries/

2. Pomerantz, J.: Learning in Three Dimensions: Report on the EDUCAUSE/HP Campus of the Future Project. ECAR research report. (2018) 
3. Yale University.: Blended Reality Applied Research Project. New Haven, Connecticut (2018). Retrieved from: https://blendedreality.yale.edu/2017-18-teams/immersive-toolslearning-basic-anatomy

4. Massachusetts Institute of Technology: Collaborative Learning Experiences in Virtual Reality (CLEVR). Cambridge, Massachusetts (2018). Retrieved from: https://education.mit.edu/portfolio_page/clevr/

5. Lieberman, M.: Creative Course Finder: Journalism Meets Virtual Reality. Inside Higher Ed. (2018, July 11). Retrieved from: https://www.insidehighered.com/digitallearning/article/2018/07/11/journalism-students-create-virtual-reality-stories

6. Lieberman, M.: Trial and Error: Virtual Reality 'as Memorable as the O.J. Simpson Case'. Inside Higher Ed. (2018, May 16). Retrieved from: https://www.insidehighered.com/digitallearning/article/2018/05/16/crime-scene-simulation-uses-virtual-reality-unite-disparate

7. Lieberman, M.: Q\&A: What Virtual Reality Can (and Could) Do. Inside Higher Ed. (2018, March 28). Retrieved from: https://www.insidehighered.com/digitallearning/article/2018/03/28/expert-virtual-reality-believes-its-higher-ed-impacts-are-still

8. Resnick, M.: Virtual Reality (VR) in Higher Ed. Gartner Blog Network. (2017, August 3) Retrieved from: https://blogs.gartner.com/marty-resnick/2017/08/03/virtual-reality-vr-inhigher-ed/

9. University of the Pacific: Scholarly Commons. Stockton, California (2016). Retrieved from:

10. Cliscagne, J., Prescott, J., Turton, T., Uz-Zaman, S.: Robb Garden Building. Building Information Modeling Final Projects, Scholarly Commons, University of the Pacific (2017). Retrieved from: https://scholarlycommons.pacific.edu/bim projects/4/

11. Koyoma, J., Mendoza, D., Sicam, K.: Robb Garden Community Resource Center, Building Information Modeling Final Projects, Scholarly Commons, University of the Pacific (2017). Retrieved from: https://scholarlycommons.pacific.edu/bim projects/1/

12. Hall, N., Laherty, J., Cook, M., McDonald, R., \& Hardesty, J.: LG-73-17-0141-17. Institute of Museum and Library Studies Grants (2017) Retrieved from: https://lib.vt.edu/researchlearning/lib3dvr.html 